$1-1-1981$

\title{
An Entrenched Bill of Rights for the United Kingdom: The Constitutional Dilemma
}

Christian G. Fritz

University of New Mexico - School of Law

Follow this and additional works at: https://digitalrepository.unm.edu/law_facultyscholarship

Part of the Law Commons

\section{Recommended Citation}

Christian G. Fritz, An Entrenched Bill of Rights for the United Kingdom: The Constitutional Dilemma, 10 Anglo-American Law Review 105 (1981).

Available at: https://digitalrepository.unm.edu/law_facultyscholarship/18

This Article is brought to you for free and open access by the UNM School of Law at UNM Digital Repository. It has been accepted for inclusion in Faculty Scholarship by an authorized administrator of UNM Digital Repository. For more information, please contact amywinter@unm.edu, Isloane@salud.unm.edu,sarahrk@unm.edu.

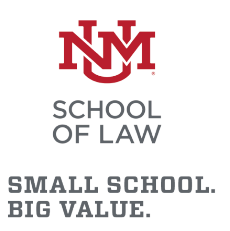

BIG VALUE. 


\title{
An Entrenched Bill of Rights for the United Kingdom: \\ The Constitutional Dilemma
}

\author{
by \\ CHRISTIAN G. FRITZ
}

REPRINTED FROM THE ANGLO-AMERICAN LAW REVIEW

Vol. 10, No. 2 (April,1981) 


\title{
AN ENTRENCHED BILL OF RIGHTS FOR THE UNITED KINGDOM: THE CONSTITUTIONAL DILEMMA
}

\author{
By CHRISTIAN G. FRITZ*
}

Lord Scarman's delivery of the twenty-second Hamyln lecture precipitated a spate of commentary on the nature of the British constitution. ${ }^{1}$ This article considers the most controversial aspect of his lecture; a proposal for a written Bill of Rights. The reinvigorated constitutional dispute revolves around whether entrenchment of such a bill could bind Parliament without a written constitution. ${ }^{2}$ Implicit in Lord Scarman's proposal is the largely overlooked and frequently misunderstood concept of fundamental law. Explicit consideration of this concept appears to offer an important criterion for the viability of his proposal. This article suggests that entrenchment is not possible because it represents the creation of fundamental law by an Act of Parliament, something that for all its authority Parliament cannot do. Entrenchment attempts to alter fundamentally the structure of government without a corresponding change in constitutional premises. Proposals for entrenchment reflect a desire to achieve constitutional change without discarding the traditional theory of parliamentary sovereignty. Obviously constitutional reforms would fare better if they were compatible with the holy orthodoxy associated with A.V. Dicey's view of the British constitution. ${ }^{3}$ Unfortunately the essence of fundamental law and the nature of entrenchment force a conflict between theory and reform.

Although susceptible to various jurisprudential definitions, fundamental law within democratic societies derives its essential characteristics from two widely held political beliefs or axioms.

The author is a member of the California Bar and is presently a graduate student in history at the University of California, Berkeley. He would like to express his appreciation to Joseph J. Franaszek, David W. Greenthal and Professors Charles W. Royster and Roger J. Traynor for commenting on an earlier draft of this paper. 
In every free state, no matter what the structure and power of the government, the ultimate source of government's authority and legitimacy is acknowledged to be the consent of the governed. A corollary to this belief holds that such consent be expressed by some majority. Neither of these two propositions are inevitable nor logical, but they are widely accepted political truths that suggest prexequisites for the creation of fundamental law in free societies.

Fundamental law may be understood to be the conscious expression of the governed on how government operates and is restrained. Fundamental law is preeminent because it is derived from the source of the highest political authority in any democratic society: the consent of the governed. This expression of the governed is therefore essentially different from the ordinary decisions made by government through representatives acting under the aegis of the people. The creation of fundamental law is an act confined to the governed. Although ascertaining the sense of the populace may require the use of delegates or representatives, ultimate approval rests with the governed and this fact emphasizes the momentous character of fundamental law.

As the governed's consent must be explicitly articulated and understood to be a basic charter of government it must inevitably take written form. The tacit acceptance of constitutional "conventions" is a form of consent, but it lacks a conscious deliberation that propounds the fundamental restraints on government through a written document. Parchment is necessary to fundamental law not because its tangibility thereby produces a mythical power to restrain government, but because a written constitution embodies the explicit consent and deliberation of the governed and provides a concrete frame of reference within which the continued acceptance of those restraints by the people gives force and direction to the document's interpretation.

Consensual understandings in the nature of British constitutional "conventions" fall outside this description of fundamental law. Britain does not have a fundamental law, its government may be defined and restrained in practice but not by the means of a constitutional charter. By definition, fundamental law can never be the creature of ordinary legislation for if the legislature can create or abrogate fundamental law at will then no extraordinary legal means, derived from the governed, exist to restrain government.

Ultimately, the effectiveness of fundamental restraints rests with their observance by government. ${ }^{4}$ This observance is secured when both the populace and their governors perceive the transcendant importance of fundamental law, subject to change only by extraordinary means. Constitutional "conventions" may also generate a political ethos that acts to restrain government but, 
as noted, their source and nature differs from fundamental law. Government is predisposed against ignoring fundamental law, because it accepts such law's fundamentality. Moreover, it would be loathe to incur the political wrath of its constituents by repudiating their authority - the ultimate source of political power.

The foregoing characterization of fundamental law identifies the impediment to entrenchment. In effect, entrenchment would allow Parliament to establish fundamental law by legislative fiat. By protecting certain rights through entrenchment Parliament prevents their abrogation except by a specified procedure. In the interim, the law courts, previously bound to obey the last expression of Parliament would have to determine: 1) if a conflict existed between an Act of Parliament and the entrenched bill and, 2) if so, whether the special procedures authorizing such contravention were met. However cautiously proponents of entrenchment characterize this process, functionally it entails the power of judicial review. No doubt the courts would seek to reconcile potential conflicts wherever possible through interpretation. But when unable to do so a court would have to invalidate an Act of Parliament if it contravened the entrenchment bill without first securing the requisite special majority. Insisting that an entrenched bill is unalterable by an ordinary Act of Parliament implies the existence of a higher law. The concomitant duty of courts to check legislative efforts to abrogate the provisions of the entrenched bill is a restraint upon government imposed by virtue of fundamental law. These logical implications of entrenchment cannot be reconciled with the accepted understanding of parliamentary sovereignty except by tortuous analysis.

The argument that no substantive restraints are created by imposing procedural requirements before a future Parliament can legislate in a given area lacks persuasiveness. Chat acterizing entrenchment as procedural does not imply the erection of a barrier to legislative action but rather the perfunctory compliance with required forms. Yet a distinction between."form" and "substance" is highly artificial when the professed objective of entrenchment is to limit the behaviour of government. Even the word "entrenchment" suggests that the procedure is designed to frustrate legislative attempts to alter the entrenched bill. The real issue is not one of semantics but one of basic assumptions held about government. Are there certain interests of the individual that should be protected from potential interference by Parliament through the means of fundamental law? The implications of an affirmative answer include a radically different perception of the legislature and the role of the courts. A desire to avoid a radical departure perhaps explains why British scholars have resorted to highly attenuated reasoning in their efforts to justify entrenchment.

Whether parliamentary sovereignty is "continuing" (as some 
opponents of entrenchment assert) or "self-embracing" (as some proponents of entrenchment maintain) is irrelevant to resolving whether entrenchment is possible. ${ }^{5}$ In either case Parliament by its nature is incapable of enacting fundamental law. Likewise, how one defines the source of parliamentary sovereignty does not resolve whether or not entrenchment is feasible. ${ }^{6}$ Many eminent constitutionalists believe entrenchment impossible because it conflicts with a basic political fact of British parliamentarianism: that the courts must obey the last expression of Parliament's will. ${ }^{7}$ On the other hand proponents of entrenchment maintain that judicial obedience is a legal principle that may be changed by Parliament. ${ }^{8}$ Both views, it is submitted, are incorrect. The former position is deficient because it rejects entrenchment on the grounds that judicial obedience is so basic to British constitutionalism that it cannot be altered save by revolution or political realignment. This view erroneously assumes that the United Kingdom is bound by fundamental law albeit labeled "the ultimate political fact." "As already argued, entrenchment must fail because it is inherently impossible for even a theoretically sovereign legislature to create fundamental law. This argument also disposes of the theory that judicial obedience is a legal arrangement easily changed by Parliament, if that rearrangement would create fundamental law.

The debate over entrenchment has prompted both sides to advance cases that purportedly support their respective positions. Here too, the central issue has been overlooked. Opponents of entrenchment frequently refer to the lack of any precedents for proposals such as Lord Scarman's. ${ }^{10}$ But the absence of precedents does not foreclose the legitimate creation of fundamental law that could bind Parliament. The issue is, as Lord Scarman put it, a matter of a "will to change" and not the resolution of a typical legal problem within the confines of the common law. For this reason too, reliance by opponents of entrenchment on the dicta in Edinburgh Railway Co. v. Wauchope (1842) is misplaced. ${ }^{1}$ The Wauchope case merely reflected the current understanding of the relationship between Parliament and the law courts in the mid-nineteenth century. Historically this relationship was not inevitable and is not now fundamental law. Thus, whether the courts could look behind the parliamentary rolls - could, in effect, exercise judicial review - depends only on the willingness of Britons to establish a "new constitutional settlement."

Proponents of entrenchment primarily rely on three Commonwealth decisions in their argument that such a technique could be used to bind the Mother of Parliaments. ${ }^{12}$ Reliance upon these cases is misplaced for several reasons. First, the Commonwealth cases arise in a different setting from proposed entrenchment under the British Parliament. The cases are inapposite to the extent they do not involve the creation of fundamental law by the 
legislature of an independent state. Two case, one arising out of South Africa (Harris v. Minister of the Interior (1952)) and the other out of Ceylon (Bribery Commissioner v. Ranasinghe (1965)), involved the application of constitutional provisions enacted for the operation of colonies by the British Parliament. ${ }^{13}$ Moreover, the "manner and form" restrictions upheld in Attorney-General of New South Wales v. Trethowan (1932) were implied from the Colonial Laws Validity Act, 1865, also passed by the British Parliament. ${ }^{14}$ Thus, the entrenchment involved in these cases consisted of conditions imposed by a sovereign state upon its colonies and were not attempts at self-limitation by a theoretically sovereign parliament. These entrenchment-like restrictions arising within the Commonwealth are, according to Justice Dixon's High Court opinion in the Trethowan case, "not to be determined by the direct application of the doctrine of parliamentary sovereignty, which gives to the Imperial Parliament its supremacy over the law."1 5 Rather, "it is the law, derived mediately or immediately from the Imperial Parliament" that must be consulted to determine the legal efficacy of entrenchment. ${ }^{16}$ Secondly, with the exception of Harris, the cases did not involve the entrenchment of individual rights designed to act as a bulwark against future parliaments. In Trethowan the "entrenchment" imposed a referendum before the Upper House could be abolished and in Ranasinghe "entrenchment" meant changing a constitution in accordance with its terms. Such provisions place far less limitations on substantive matters a later legislature may wish to deal with than does the entrenchment of a Bill of Rights modeled after the European Convention of Human Rights.

However, the three cases do suggest that one might argue that entrenchment (i.e. different procedures required for different legislative functions) is not incompatible with a theory of parliamentary sovereignty. Nonetheless, the differences in political status between the United Kingdom and the Commonwealth are significant. Until a colony has attained independence, the dominion by the Mother Parliament intercedes between the political relationship of the Commonwealth populace and their governors. Entrenchment effected in this political context is not a selfimposed limitation by an independent sovereignty. Only an independent state that embraces the doctrine of parliamentary sovereignty would present a comparable basis for entrenchment within Britain. In both situations it is contended that entrenchment is not possible by the means of legislative fiat.

It has been suggested that despite the theoretical claims for sovereignty, the United Kingdom has fundamental law that binds Parliament through a constituent document - the Act of Union. ${ }^{17}$ The sweeping language in the Act has been regarded by some as an attempt to make these provisions unrepealable i.e. to entrench them. ${ }^{18}$ Others cite the subsequent abrogation of these provisions 
as proof that the Act of Union is not fundamental law. ${ }^{19}$

Proponents of entrenchment who maintain that the Act constitutes fundamental law confuse the nature of such law. Professor Smith regards the Universities (Scotland) Act of 1853 as a breach of the Act of Union, but believes that the breach does not deprive the remaining provisions of the Act of their fundamentality. ${ }^{20}$ Although he is reluctant to claim judicial review for the courts, he cites the oath requiring judges to uphold "the laws and usages of this realm" as the authority to confine the legislature within the area conferred to it by the constituent document. ${ }^{21}$ Such review would be justified where "really important issues are involved - such as those affecting the Church and the jurisdiction of the Supreme Court." 2 In most cases, however, the courts "would be prepared to construe legislation so as to reconcile it, if possible, within the limits set in 1707.", 3 Professor Mitchell also views the Act as containing fundamental law, but "the thing which is 'entrenched' is not, for a variety of reasons, anything which is absolutely constant." 24 According to him, fundamental provisions do not take on a fixed aspect but are constantly evolving and change their meaning with the passage of time. The phrases "in all time coming" and "forever" are not to be taken literally; such phraseology was common in Scottish Acts of the period. $^{25}$ Mitchell's point is that certain provisions of the Act of Union are fundamental law placing limits on the United Kingdom Parliament, but that they go to "essentials and not detail."26 Mitchell, unlike Smith, does not consider the Act of 1853 a breach of fundamental law, characterizing the Act as affecting "details" rather than "essentials." 7

Both Professors Smith and Mitchell incorrectly denominate the Act of Union fundamental law. If my understanding of fundamental law is accepted, the Act of Union cannot so be regarded because it is not consciously understood and accepted as a restraint upon the operation of government. ${ }^{28}$ Rather, it was a political concession to Scotland that could and was later retracted when the political climate had changed. Moreover, Professor Mitchell's willingness to regard the binding effect of fundamental law as varying with a given political context, undermines the nature of the concept. The meaning given to that fundamental law may well be constantly evolving relative to its political settings. But fundamental law is either perceived as fundamental or it is not. If fundamental, there will be a felt need to interpret it so as to accommodate all subsequent legislation or else constitutionally alter it. ${ }^{29}$ But at all times its supremacy and binding effect will be acknowledged. This shared perception in and of itself constitutes the primary strength of fundamental law - an ideology that insures that government operates within the ambit of certain limits.

The United Kingdom's membership in the European Com- 
munity poses a potential challenge to the supremacy of Acts of Parliament. The European Communities Act, 1972, presents the British courts with possible conflicts between national and Community law. ${ }^{30}$

Section 2(1) of the Act gives present and future Community law automatic legal effect within the United Kingdom. Section $3(1)$ requires that British courts interpret Community law in accordance with relevant European Court decisions or submit the issue to that court. Finally, s.3(2) requires British judges to take judicial notice of "the Treaties, of the Official Journal of the Communities and of any decision of or expression of opinion by, the European Court on any such question" as referred to in s.3(1).

The significance of these provisions to the traditional notion of parliamentary sovereignty is the inherent conflict between the implication of Community law supremacy and British national law. Two Treaty articles in particular bode ill for the theoretical operation of parliamentary sovereignty. When matters of Community law arise in cases pending in national tribunals, Article 177 gives the Court of Justice jurisdiction by way of a preliminary ruling solicited by and rendered to such tribunals. ${ }^{31}$ Article 189 describes three Community Acts that have binding effect within Member States to varying degrees. ${ }^{32}$ Although the Treaty did not expressly establish the precedence of Community over national law within the context of a "new.legal order," the Court of Justice has so held. ${ }^{33}$ The result is that s.3(2) of the European Communities Act - which requires application of the Court of Justice's decisions - has far-reaching consequences.

Furthermore, the Act itself provides what some consider is the binding feature giving primacy to Community law. Section 2(4) deals with possible conflicts between Community law and future Acts of Parliament. It provides in part that: "any enactment passed or to be passed other than one contained in this Act, shall be construed to have effect subject to the foregoing provisions of this section." Some scholars view the passage of the European Communities Act as the British acceptance of the concept of a nouvel ordre jurdique. ${ }^{34}$ In their view the Community represents a legal revolution, acknowledged by the other Member States, changing the relationship between state courts and their municipal law. ${ }^{35}$ According to this view the United Kingdom has accepted a basic alteration in its law through the enabling legislation of the European Communities Act.

Professor Mitchell, for one, maintains that the Act obligates British judges to scrutinize legislation for conflicts with Community law. Traditional subservience to Parliament is incompatible with their new role. ${ }^{36}$ In fact:

Unless there has been a renunciation of the Treaty, this adherence to this "deep rooted allegiance to the Parliament of the day" amounts to 
a betrayal of the judicial role. It amounts to a determination at all costs to maintain a legal theory against the establishment by legitimate means of a new polity involving a new legal order and a change in the fundamental hypothesis. $^{37}$

In the light of Britain's membership in the European Community, some observers have asked "whether the principle of the primacy of Community law ... will spell the end of the British doctrine of parliamentary sovereignty." 38 Ingenious attempts have been made to reconcile Community law primacy with parliamentary sovereignty. Professor Wade suggests that Parliament might pass an annual bill asserting the supremacy of Community law. In the alternative, he suggests a change in the conventional wording of enactments, perhaps including "some short formula added at the end such as 'this Act conforms to the European Communities'.",39 Professor Phillip's position is that since a simple majority can effect constitutional changes, the primacy of Community law (as well as any other provision) can only be guaranteed if made part of a written constitution. ${ }^{40}$ Another suggestion to harmonize the two sources of law is to recognize a constitutional convention restraining Parliament from legislating adversely to Community law. ${ }^{41}$. Still another solution to the perceived constitutional dilemma is "the establishment of a permanent Parliamentary Standing Committee for the Scrutiny of Legislation Concerning the European Community." 42 This committee would function both to avoid enactment of legislation in conflict with Community law (by indicating what changes would be required) and to make recommendations insuring harmony between new regulations and existing statutes.

Subsequent to most of this academic speculation some British courts have conceded the primacy of Community law, primarily through the influence of Lord Denning MR. ${ }^{43}$ In H.P. Bulmer, Ltd. v. J. Bollinger S.A., Lord Denning said that "when we come to matters with a European element, the treaty is like an incoming tide. It flows into the estuaries and up the rivers. It cannot be held back." 4 Despite the judgements of the Master of the Rolls, the cases cited do not necessarily establish the omnipotence of Community law, even though they do herald a growing recognition by the British legal community of a nouvel ordere jurdique. ${ }^{45}$ Rather, the decisions remain consistent with traditional principles of parliamentary sovereignty and dualism. British judges can always argue as follows: the European Communities' Act adopts Community law; it is an Act of Parliament that follows earlier Acts or decisions of common law; therefore it overrides existing law. The true test of primacy will occur when a future Act of Parliament directly conflicts with Community law.

How the British courts will decide this potential conflict is 
uncertain. Most likely, in the absence of Parliamentary support for the courts to assume a more aggressive role in dealing with Community law, the British courts will follow the traditional path and give effect to the wishes of the "latest Parliament." Nonetheless, Professor Mitchell and his adherents present a clearer picture of political reality when they claim a new legal order has resulted from Britain's membership in the European Community. One indisputable result of the Community has been the growing legal integration between Members. It stands to reason that the United Kingdom will not prove immune to this process. In the same manner that granting independence to former colonies politically "binds" Parliament, so do political pressures insure the continued observance of Community law.

These actual, political forces are persistent reminders that Dicey's classical theory is no longer an accurate description of the British form of government. This gap between theory and practice has prompted some, notably Lord Scarman, to propose reforms that would bring Britain's legal and constitutional system into line with political reality. Nonetheless, this boldness has been tempered by the assertion that entrenchment need not discard the time-honored theory of parliamentary sovereignty. But even if this procedure were possible - if it was not an attempt to create fundamental law - proponents of entrenchment would have to swallow the bitterest pill of all: the acceptance of judicial review. Entrenchment of provisions designed to preserve human rights necessarily implies judicial review and therefore directly conflicts with parliamentary sovereignty.

According to some constitutional reformers, the effect of entrenched provisions would simply require judges to ascertain if the legislative component had properly combined to achieve a given legislative purpose. The implication is that ensuring that the necessary "manner and form" is used is not such a different role from that which the courts presently assume. ${ }^{46}$ Entrenchment would:

require the judges who interpret and enforce the law merely to be able to recognize the difference between a half and two-third majority rather than apply their minds to such questions as whether the legislature has infringed "those canons of decency and fairness which express the notions of justice of English-speaking people.", 7

If this description is accurate, proponents could reasonably argue that a logical extension of The Prince's Case (1606) could justify the judicial scrutiny required by entrenchment. ${ }^{8}$ The description, however, is open to serious doubt. It fails to take proper account of the inherently abstract nature of provisions dealing with human rights. If a Parliament should attempt, with- 
out proper "manner and form," an outright repeal of an entrenched provision, the judicial role would be as proponents describe. Repeal represents the most extreme (but only one) type of legislative interference with entrenched provisions. It is far more likely that challenges to entrenchment will arise in a less direct fashion while still contravening the letter or spirit of entrenched provisions. As pointed out earlier, to decide whether an Act of Parliament complies with due "manner and form," the courts must first determine the effect of legislation on the entrenched provisions. This process of examining legislation and entrenched provisions for possible conflict entails giving meaning to the entrenched provisions.

Proponents of entrenchment are too optimistic about applying entrenched provisions to legislative acts while avoiding the "unEnglish imponderables typical of the American First Amendment provisions. . . ." 9 However reassuring it is to a legal community accustomed to strict interpretation of Acts of Parliament, human rights resist, if they do not defy efforts to contain their interpretation to the "four-corners" of an Act. ${ }^{50}$ Whether the provisions are stated abstractly or with particularity the court is faced with the inherent task of striking a balance between state and individual interests. ${ }^{51}$ Although the British courts may avoid having to interpret such phrases as "due process" or "clear and present danger" they will have their own equally ambiguous terms to interpret; "imponderables" that confront any court grappling with the protection of human rights. ${ }^{52}$

British observers of the American legal system have long expressed their misgivings about the amount of discretion placed in the hands of the United States Supreme Court. Through entrenchment, however, the interpretative role of the British judges will be infused with a considerable amount of discretion. ${ }^{53}$ Needless to say, a grant of this authority is heady wine to a judiciary that has for so long faithfully observed the principle of complete obedience to the last word of Parliament. ${ }^{54}$ Judicial review represents such a dramatic shift in the present constitutional position that its assumption by the courts is frequently dismissed out of hand.

Nonetheiess, participation in the European Convention of Human Rights has exposed the United Kingdom to the practice of judicial review. ${ }^{5}$ In 1966 the United Kingdom lodged a declaration in accordance with Article 25 of the Convention. "Consequently, any person, even a national acting against his own government, who claims to be prejudiced by a violation of the Convention may, after exhaustion of local remedies, apply to the Commission for relief with the result that an Act of Parliament, an executive act, any judicial decision, including decisions of the House of Lords may become subject to the various remedies which 
the Convention envisages." 56 A number of cases, most notably Golder $v$. United Kingdom, 57 have made it impossible to ignore the dramatic influence of European Court of the Human Rights sitting in Strasbourg on British domestic affairs. According to Professor Mann: "there now exists, unbeknown to many, an international system of fundamental laws and judicial review" within the area of human rights covered by the Convention that makes the issue "Iess the incorporation of the Convention into English law" than whether to accept "domestic as opposed to foreign judicial review ..." 8

A few scholars are willing to assert that judicial review is theoretically possible under the present constitutional arrangements. ${ }^{59}$ They concede that most lawyers and scholars deny British courts such power but appeal to the constitutional experience in Continental Europe and the United States. "While the British may be a peculiar people, one of their pecularities is not necessarily a monopoly of constitutional or political virtue or rectitude. Experience elsewhere is not irrelevant."6 o Furthermore, they claim that indigenous authority supports the doctrine of judicial review. Namely that the Scottish doctrine of desuetude justifies the assumption of a more active and discretionary posture, at least by Scottish judges. Moreover, the case MacCormick v. Lord Advocate ${ }^{61}$ is cited. Although judicial review was not invoked, Professor Mitchell regards the case as important because it expressly implied the possible exercise of such power in "future and different cases." $" 62$

All told, the British "authority" is meager. Judicial. subservience to Acts of Parliament has been accepted and unchallenged too long to argue persuasively that the present state of the law supports the idea of judicial review. The stronger argument for adopting fundamental law and by implication judicial review questions the irrefutability of the present understanding of the British constitution. Lord Scarman makes this argument by placing emphasis on the early English tradition favoring the codification of fundamental rights and a judicial attitude protective of such rights against the legislature. ${ }^{63} \mathrm{He}$ contends that the nature of British constitutional law makes the existence of such a tradition relevant to the current debate over entrenchment. On both points more traditional constitutionalists take issue with him. None the less, if Lord Scarman's view of constitutional law is accepted, it follows that the British courts might properly develop a more active relationship with Parliament - even to the extent of judicial review. ${ }^{4}$

The only flaw in Lord Scarman's argument - but a major one - is the impossibility of creating fundamental law through entrenchment. Entrenchment however characterized, involves a fundamental alteration of the legal and political order. An 
entrenched provision would serve the same function as a written constitution: law that the legislature could not change save by specified amendment. As fundamental law it must derive its existence from the ultimate source of legitimate authority - those governed - and not simply by legislative fiat. ${ }^{65}$ The freedom Lord Scarman seeks from the common law's conceptuality cannot alter the nature of fundamental law. Lord Scarman tacitly acknowledges this fact by suggesting that a new constitutional settlement emerge out of Parliament but with a widespread participation, perhaps culminating in a referendum by the constituents. Thus, a distinction exists between advocates of entrenchment: those who view it as a special parliamentary procedure and those who regard it as part of a solemn process requiring consultation with the fountainhead of government. The latter position is correct. For entrenchment to be effective requires some form of explicit consultation with the people.

\section{END NOTES}

1. Sir Leslie Scarman, English Law - the New Dimension, London, 1974. Sir Leslie, Lord Justice of Appeal (as he was at the time of the Hamlyn lecture) was appointed a Lord of Appeal in Ordinary on September 30, 1977.

2. Entrenchment is sometimes used to describe the process whereby an Act of Parliament incorporates a Bill of Rights but provides that any subsequent legislation will be deemed to be in compliance with that Bill unless it clearly manifests a contrary intention. Canada has so entrenched its Bill of Rights. (See $R$. $v$. a contrary intention. Cana 28 and Attormey-General v. Lavell [1974] S.C.R. 1349) Drybones [1970] S.G.R. 282 and Attomey-General v. Lavell [1974] S.C.R. 1349) Bill of Rights?" London. (1975) 45, 51-52; P. Wallington and J. McBride, Civil Liberties and a Bill of Rights, Cobden Trust, London (1976) at pp.83-94, and Labour Party, "Charter of Human Rights," Discussion Document, London (1976) at pp.7-8.

The entrenchment that Lord Scarman speaks of, and as the term will hereafter be used, involves an attempt to prevent a later Parliament from violating a Bill of Rights unless it can obtain a special majority e.g., two-thirds or three-quarters.

3. The case of Pickin $v$. British Railways Board [1974] A.C. 765 represents a most forceful restatement of Parliament's sovereignty.

4. "We must beware of persuading ourselves that freedom can be embalmed. It cannot be preserved by any institution unless that institution has muscle power deriving from human vigilance and concern." Response to Lord Scarman's proposal by the then Solicitor-General, Mr P. Archer. The Times, Dec. 14, 1974, col. 3b.

Moreover, the Lords' Select Committee on a Bill of Rights concluded that "in any country, whatever its constitution, the existence or absence of legislation in the nature of a Bill of Rights can in practice play only a relatively minor part in the protection of human rights. What is important, above all, is a country's political climate and traditions." Report of the Select Committee on a Bill of Rights, no.176, London, (1978) 29.

5. Two different theories of sovereignty, one permitting and the other precluding entrenchment have been respectively termed "self-embracing" and "continuing" 
by H.L.A. Hart. See The Concept of Law, Oxford (1971) at p.146; cf. O.H. Phillips, Reform of the Constitution, London (1970) at pp.11-14 and "Selflimitation by the United Kingdom Parliament," 2 Hastings Constitutional Law Quarterly 443 (1975). See also G. Winterton, "The British Grundnorm: Parliamentary Sovereignty Re-examined," 92 Law Quarterly Review 591 (1976) for an analysis and summary of scholarly views of parliamentary sovereignty.

6. The jurisprudential complexities surrounding the Kelsenite apex norm theorem are beyond the scope of this article. On H. Kelsen's views on the "grundnorm" see J. Stone, Legal Systems and Lawyers'Reasonings, London (1968) at pp.116-136 and "Mystery and Mystique in the Basic Norm," 26 Modern Law Review 34 (1963).

7. Professor H.W.R. Wade, one of the strongest opponents of entrenchment, gave the classic defense and reaffirmation of Dicey's view of the British constitution in "The Basis of Legal Sovereignty," Cambridge Law Journal 172 (1955). In recently delivering the thirty-second Hamlyn lecture, however, Professor Wade has suggested that "entrenchment could be made to work consistently with the dogma of parliamentary sovereignty" by imposing an obligation on judges to recognize fundamental law through the judicial oath of office. See H.W.R. Wade, Constitutional Fundamentals, London, 1980, especially Ch. 3.

8. See for example,M.A. Fazal, "Entrenched Rights and Parliamentary Sovereignty," Public Law 295 (1974).

9. Wade, "The Basis of Legal Sovereignty," supra, 188.

10. In fact they frequently cite three cases as precedents against entrenchment: Vauxhall Estates, Ltd. v. Liverpool Corp. [1932] 1 K.B. 733; Ellen Street Estates, Ltd. v. Minister of Health [1934] 1 K.B. 590 and British Coal Corp. v. The King [1935] A.C. 500.

11. "All that a Court of Justice can do is look to the Parliamentary Roll: if from that it should appear that a bill has passed both Houses and received the Royal Assent, no Court of Justice can inquire into what was done previous to its introduction, or what passed in Parliament during its progress in its various stages through both Houses." Per Lord Cambell, $8 \mathrm{Cl}$. and F. 710, 725.

12. See Attomey-General for New South Wales v. Trethowan [1932] A.C. 526; Harris v. Minister of the Interior [1952] 2 S. Afr. L.R. 428 and Bribery Commissioner v. Ranasinghe [1965] A.C. 172.

Also sometimes cited is the case of Rediffusion (Hong Kong) Ltd. v. AttorneyGeneral of Hong Kong [1970] A.C. 1136, wherein their Lordships upheld the Supreme Court of Hong Kong's assumption of jurisdiction to examine the lawfulness of proceedings of the Legislative Council. In so deciding, the Privy Council clearly distinguished between the Commonwealth setting and "principles which govern the jurisdiction of English courts to interfere in the conduct of proceedings in the fully sovereign Parliament of the United Kingdom." Rediffusion, supra, $1154 \mathrm{G}-\mathrm{H}$.

13. In Harris the Supreme Court of South Africa held that for the purposes of the Statute of Westminster, 1931, the Union Parliament was defined by its constitution - the South Africa Act, 1909. See Harris, 428 at p.464.

In Ranasinghe the Privy Council held that the Parliament of Ceylon could not amend its constitution merely by passing an Act inconsistent with it (in this case the Bribery Act, 1958), but instead had to follow the procedure for constitutional amendment embodied in no.29 of the Ceylon (Constitution) Order in Council, 1946. See Ranasinghe 172 at p.198.

14. See Trethowan, 526 at pp.540-541.

15. Attorney-General of New South Wales v. Trethowan (1931) 44 C.L.R. 394 at p.425.

16. Ibid. Nonetheless Justice Dixon alluded to the possibility of entrenchment even under the Imperial Parliament. "If before the Bill received the assent of the Crown, it was found possible ... to raise for judicial decision the question whether it was lawful to present the $\mathrm{Bill}$ for that assent, the Courts would be bound to pronounce it unlawful to do so. Moreover, if it happened that, notwithstanding the statutory inhibition, the Bill did receive the Royal assent ... the Courts might be called upon to consider whether the supreme legislative power in respect of the matter had in truth been exercised in the manner required for its authentic

17. See J.D.B. Mitchell, "Sovereignty of Parliament - Yet Again," 79 Law Quarterly 
Review 196 (1963) and T.B. Smith, "The Union of 1707 as Fundamental Law," Public Law 99 (1957) both of whom rely heavily on McCormick v. Lord Advocate [1953] S.C. 396.

18. See O.H. Phillips, Constitutional and Administrative Law 4th ed. London, (1967) at p.64.

19. See O.H. Phillips, "Self-limitation by the United Kingdom Parliament," supra, 443 at p.461.

20. See T.B. Smith, "The Union of 1707 as Fundamental law," supra, 99 at 112.

21. Ibid., 114 .

22. Ibid,

23. Ibid.

24. J.D.B. Mitchell, Constitutional Law, Edinburgh, (1964) at p.56.

25. Ibid., 55 .

26. J.D.B. Mitchell, "Sovereignty of Parliament - Yet Again," supra, 196 at p.207.

27. Ibid., at pp.206-207.

28. Professors Smith and Mitchell argue that some of those drafting the Act of Union intended it to act as fundamental law. See Smith, "The Union of 1707 as Fundamental law," supra, at p.111 and Mitchell, Constitutional Law, supra, at p.55. Even conceding this point, it is clear that the Act has long since lost whatever recognition it had originally as fundamental law. And, unlike statutory law, when the governed cease to believe in the fundamentality of a charter of government, it cannot rightly be called fundamental law.

29. No issue is taken with Professor Mitchell's statement that: "it is impossible, in any absolute sense, to confine the evolution of societies by the Statute Book." Constitutional Law, supra, at pp.58-59. The point is not the flexibility of constitutional interpretation owing to the influence of politics, but rather the undisputed authority of the interpretation of fundamental law.

30. For a detailed discussion of the Act, see J. Forman, "The European Communities Act; 1972," 10 Comm on Market Law Review 39 (1973).

31. See H. Smit and P. Herzog. The Law of the European Economic Community, $A$ commentary on the EEC Treaty, Vol. 4, (5-443) - (5-487), 1976. The authors state that: " $[t]$ he Court's ruling in an Article 177 proceeding is not in the nature of an advisory opinion that the national court which made the reference is free to disregard. On the contrary, although Article 177 is not explicit on the point, its whole thrust and purpose warrant the conclusion that the Court's ruling is binding in the proceeding in which it is rendered." Ibid., (5-485).

32. See Smit and Herzog, supra, Vol. 5, (5-591) - (5-622). A "regulation" is directly applicable to all members, a "directive" compels the member to whom it is directed to achieve a result, without specifying the manner of its achievement and a "decision" requires that member states and individuals achieve a result using particular means.

33. See N.V. Alemene Trasnport-en-Expeditie Onderneming van Gend and Loos v. Netherlands Fiscal Administration 2 C.M.L.R. 105 (1963); Costa v. Ente Nazionale Energia Elettrica (E.N.E.L.), 3 C.M.L.R. 425 (1964) and Wilhelm v. BundesKartellamt 8 C.M.L.R. 100 (1969). Quite recently the Court of Justice has reaffirmed its position that community law overrides subsequent national enactments, in a preliminary decision referred by the Pretore at Susa, Italy. See Italian Tax and Revenue Administration v. S.A. Simmenthal, Monza Italian Tax and Revenue Administration v. S.A. Simmenthal, Monza (Italy), reported in The Times, March 13, 1978, col. c-f.

34. See J.D.B. Mitchell, S.A. Kuipers and B. Gall. "Constitutional Aspects of the Treaty and Legislation relating to British membership," 9 Common Market Law Review 134 (1972).

35. Supporting the existence of a new legal order is the fact that all of Britain's fellow members in the European Community have accepted a measure (and in some cases a great deal) of community supremacy over their national law. See H.G. Schermers, "The Law as it stands on preliminary rulings," Legal Issues of European Integration 93 at pp.98-99 (1974/1).

36. See J.D.B. Mitchell, "The causes and effects of the absence of a system of public law," Public Law 95 (1965) and "The present state of public law in the United Kingdom," 15 International and Comparative Law Quarterly 133 (1966). See also J. Jaconelli, "Constitutional Review and Section 2(4) of the European Communities Act 1972" 28 International and Comparative Law Quarterly 65 (1979). 
37. See J.D.B. Mitchell et. al., "Constitutional Aspects of the Treaty and legislation relating to British membership," supra, at p.146.

38. See F.A. Trindade, "Parliamentary Sovereignty and the Primacy of European Community law," 35 Modern Law Review 375 (1972).

39. H.W.R. Wade, "Sovereignty and the European Communities," 88 Law Quarterly Review 1 at p.4 (1972).

40. See O.H. Phillips, Reform of the Constitution, supra, at pp.145-147.

41. See A. Martin, "The Accession of the United Kingdom to the European Communities: Jurisdictional Problems," 6 Common Market Law Review 7. at pp.23-25 (1968).

42. See F.A. Trindade, "Parliamentary Sovereignty and the primacy of European Community law," supra, 396.

43. See Aero Zipp Fasteners, Ltd. v. YKK Fasteners (U.K.) Ltd. [1973] 11 C.M.L.R. $819 ;$ Esso Petroleum Co. Ltd. v. Kingswood Moters (Addlestone) Ltd. [1973] 3 All E.R. 1057; H.P. Bulmer, Ltd. v. J. Bollinger S.A. [1974] 2 All E.R. 1226 ; Application des Gaz S.A. v. Falks Verites, Ltd. [1974] 3 All E.R. 51; Schorsch Meier G.m.b.H.v. Hennin [1974] 3 W.L.R. 823;Amies v. Inner London Education Authority [1977] 2 All E.R. 100; Rio Tinto Zinc Corp.v. Westinghouse Electric Corp (No.1) [1977] 15 C.M.L.R. 420; James Buchanan and Co. Ltd; v. Babco Forwarding and Shipping (U.K.) Ltd. [1977] 2 W.L.R. 107 and Maxim's Ltd. $v$. Dye [1978] 2 All E.R. 55.

44. See Bulmer v. Bolinger, supra, $123 \mathrm{H} \cdot \mathrm{J}$. Lord Denning proceeded to describe the concrete implications of this metaphor: "Any rights or obligations created by the Treaty are to be given legal effect in England without more ado. Any remedies or procedures provided by the Treaty are to be made available here without being open to question. In future, in transactions which cross the frontiers, we must no longer speak and think of English law as something on its own. We must speak and think of Community law, of Community rights and obligations, and we must give effect to them." Ibid., 1232B. 45. There is some indication that the "incoming tide" of Community law is reaching
new high water marks. Upon the establishment of a new European information service by the British sections of the International Union of Local Authorities and the Council of European Municipalities, Sir Meredith Whittaker, Chairman of the British sections, said: "In the past we have not taken European affairs as seriously as we should have done. Now local government is playing a much bigger part on the European stage and this campaign is a recognition of our growing awareness." The Times, July 5, 1978, col. $2 \mathrm{f}$.

46. Sir Ivor Jennings speaks of a "manner and form" in discussing the possibilities of entrenchment whereas G. Marshall uses the phrase "forms and procedures." See Jennings, The Law and the Constitution, supra, Chap. IV and Marshall, Constitutional Theory, supra, at pp.34-53. Both imply a procedural requirement Parliament must fulfil before it can legislate and for the sake of convenience, "manner and form" will denote both phrases.

47. See Marshall, Constitutional Theory, supra, at p.127, footnote 3. Marshall quotes Justice Felix Frankfurter in Malinske v. New York 324 U.S. 401 at p.416 (1945).

48. The case is taken as authority for judicial examination of a statute's validity. The court held, in part, that an Act of Parliament was conclusive only if it followed the proper form in its enactment. See The Prince's Case 8 Co. Rep. la at 20b (1606).

Even the staunchest traditionalists agree that courts properly assume jurisdiction to ascertain that legislation has the required assent of all three elements. (See for example, Phillips, Constitutional and Administrative Law, supra, at p.72.) If, therefore, it is possible to redefine an "Act of Parliament" for different purposes, judicial examination of the necessary form required for such legislation could be supported under the reasoning of The Prince's Case.

Even so, more recent Australian cases demonstrate the practical limitations of how far a court can inquire into the correctness of what happens in the process of parliamentary enactment. See Clayton v. Heffron (1960) 105 C.L.R. 214; Cormack v. Cope (1974) 131 C.L.R. 432; Victoria v. Commonwealth (1975) 7 A.L.R. 1 and Western Australia v. Commonwealth (1975) 7 A.L.R. 159.

49. See Marshall, Constitutional Theory, supra, at p.129.

50. An excellent example of the widely held assumption that British judges are essentially apolitical but would become politicalized if given the power of judicial review is found in a report advocating the creation of a special constitutional 
court in the event a Bill of Rights is adopted; "Insofar as our judges would become more politically controversial, and their appointments politically motivated, all the problems could be focused on to the one court, so that the other courts would not be too badly tainted." P. Wallington and J. McBride, Civil Liberties and a Bill of Rights, Cobden Trust, London (1976) at p.104. supra, at p.104.

51. Lord Scarman, as with most of the other proponents of a Bill of Rights, favors modeling a Bill of Rights after the European Convention on Human Rights. Articles 9 and 10 of the Convention insure blanket freedom of thought, belief, speech etc. subject only "to such limitations as are prescribed by law and are necessary in a democratic society ... "Determining what is necessary in a democratic society is on the same level of abstraction as Justice Frankfurter's test of "the notions of justice of the English-speaking people." Malinske v. New York, supra.

52. Although most British lawyers consider the abstractions involved in interpreting a Bill of Rights dangerous, one official government body has . suggested that hypothetically these same qualities are desirable. "The generality of a Bill of Rights makes it possible for the interpretation of such a document to evolve in accordance with changing social values and needs. This process of giving fresh meaning to basic human rights - and the obligations which flow from them from generation to generation is valuable for its own sake, as a means of educating public opinion, and as a rallying point in the State for all who care deeply for the ideals of freedom." Standing Advisory Commission on Human Rights, "Bill of Rights, A discussion paper," Belfast. (1976) at p.10.

53. Even those who seek to align Britain's international obligations without entrenching a Bill of Rights sometimes overlook the implications for judicial review in their proposals. For example, the Society of Conservative Lawyers has recommended "that the European Convention of Human Rights be statutorily incorporated in English law and given overriding effect." Conservative Political Centre. "Another Bill of Rights?" London (1976) at p.23. Even if "overriding effect" only refers to existing statutes, how the courts will apply the Convention to other statutory law invests them with judicial power to deny effect to Acts of Parliament based on their interpretation of the abstract provisions protecting human rights in the Convention.

54. In recent times a most dramatic example of judicial subservience to Parliament's will arose in the case of Burmah Oil Co. v. Lord Advocate [1965] A.C. 75. See A. Goodhart, "The Burmah Oil case and War Damage Act 1965," 82 Law Quarterly Review at p.97 (1966) and R.J. Traynor, "Quo Vadis, Prospective Overruling: A Question of Judicial Responsibility," 28 Hastings Law Joumal at p.533 (1977).

55. See F.A.Mann, "Britain's Bill of Rights," 94 Law Quarterly Review at p.512 (1978).

56. Ibid., at p.521.

57. European Court of Human Rights, Series A, Vol. 18 (1975).
58. F. A. Mann, "Britain's Bill of Rights," supra, at p.533.

59. See Mitchell, Constitutional Law, supra, at pp.82-91.

60. Ibid., at p.83.

61. [1953] S.C. 396.

62. See Mitchell, Constitutional Law, supra, at p.87.

63. Scarman, English Law, supra, at p.16. Lord Scarman argues for the veracity of H. Lauterpacht's analysis of this early tradition. See Lauterpact, Intermational Law and Human Rights, London (1950) Chap.8. See also, P. Allott, "The Courts and Parliament: Who Whom?" 38 Cambridge Law Journal at p.79 (1979).

64. The causal connection between how British constitutional law is perceived (in particular the view of parliamentary sovereignty) and the logical possibility of judicial review has been pointed out by Professor Mitchell. See Mitchell, Constitutional Law, supra, at pp.87-89.

65. "The fundamental terms under which we all live together in a single political community are matters quite different in essence from a Bill to amend the Companies Act, or even a Bill to amend the criminal law. It should be beyond the competence of legislators appointed for a single Parliament to change them." G.W. Keeton, Government in Action, London (1970) at pp.250-251. 